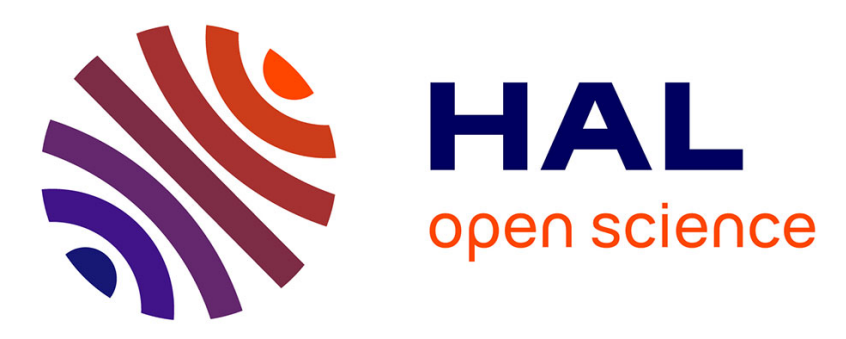

\title{
Borinic acids as new fast-responsive triggers for hydrogen peroxide detection
}

Blaise Gatin-Fraudet, Roxane Ottenwelter, Thomas Le Saux, Thomas Lombès, Aurélie Baron, Philippe Durand, Stéphanie Norsikian, Gilles Doisneau, Yann Bourdreux, Dominique Guianvarc', et al.

\section{To cite this version:}

Blaise Gatin-Fraudet, Roxane Ottenwelter, Thomas Le Saux, Thomas Lombès, Aurélie Baron, et al.. Borinic acids as new fast-responsive triggers for hydrogen peroxide detection. 2020. hal-03016626

\section{HAL Id: hal-03016626 \\ https://hal.science/hal-03016626}

Preprint submitted on 20 Nov 2020

HAL is a multi-disciplinary open access archive for the deposit and dissemination of scientific research documents, whether they are published or not. The documents may come from teaching and research institutions in France or abroad, or from public or private research centers.
L'archive ouverte pluridisciplinaire HAL, est destinée au dépôt et à la diffusion de documents scientifiques de niveau recherche, publiés ou non, émanant des établissements d'enseignement et de recherche français ou étrangers, des laboratoires publics ou privés. 


\title{
Borinic acids as new fast-responsive triggers for hydrogen peroxide detection.
}

\author{
Blaise Gatin-Fraudet, ${ }^{[a b] \S}$ Roxane Ottenwelter, ${ }^{[a] \S}$ Thomas Le Saux, ${ }^{[c]}$ Thomas Lombès, ${ }^{[a]}$ Aurélie \\ Baron, ${ }^{[a]}$ Philippe Durand, ${ }^{[a]}$ Stéphanie Norsikian, ${ }^{[a]}$ Gilles Doisneau, ${ }^{[b]}$ Yann Bourdreux, ${ }^{[b]}$ Dominique \\ Guianvarc'h, ${ }^{[b]}$ Marie Erard, ${ }^{[d]}$ Ludovic Jullien, ${ }^{[c]}$ Dominique Urban ${ }^{*[b]}$ and Boris Vauzeilles. ${ }^{*[a]}$
}

Dedicated to Professor Jean-Marie Beau on the occasion of his $72^{\text {nd }}$ birthday.

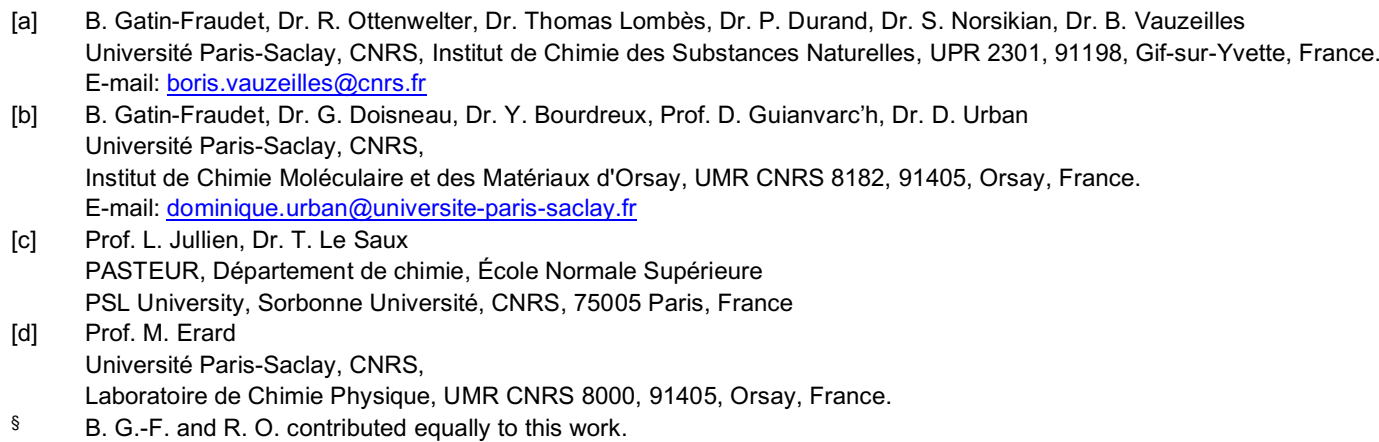

Supporting information for this article is given via a link at the end of the document

\begin{abstract}
Detection of hydrogen peroxide $\left(\mathrm{H}_{2} \mathrm{O}_{2}\right)$, which is responsible for numerous damages when overproduced, is crucial for a better understanding of $\mathrm{H}_{2} \mathrm{O}_{2}$-mediated signalling in physiological and pathological processes. For this purpose, various "off-on" small fluorescent probes relying on a boronate trigger have been developed. However, they suffer from low kinetics and do not allow for $\mathrm{H}_{2} \mathrm{O}_{2}$-detection with a short response time. Therefore, more reactive sensors are still awaited. To address this issue, we have successfully developed the first generation of borinic-based fluorescent probes containing a coumarin-scaffold. We determined the in vitro kinetic constants of the probe toward $\mathrm{H}_{2} \mathrm{O}_{2}$-promoted oxidation. We measured $1.9 \times 10^{4} \mathrm{M}^{-1} \cdot \mathrm{s}^{-1}$ as a second order rate constant, which is 10000 faster than its boronic counterpart $(1.8 \mathrm{M}$ $\left.{ }^{1} . s^{-1}\right)$. This remarkable reactivity was also effective in a cellular context, rendering the borinic trigger an advantageous new tool for $\mathrm{H}_{2} \mathrm{O}_{2}$ detection.
\end{abstract}

Reactive oxygen species (ROS) are involved in various physiological processes. In particular, hydrogen peroxide $\left(\mathrm{H}_{2} \mathrm{O}_{2}\right)$ plays a critical role in the regulation of numerous biological activities as a signalling molecule. ${ }^{[1]}$ However, aberrant production or accumulation of $\mathrm{H}_{2} \mathrm{O}_{2}$ leads to oxidative stress conditions, which can cause lesions associated with aging, cancer $^{[2]}$ and several neurodegenerative diseases such as Alzheimer's or Parkinson's. ${ }^{[3]}$ Differentiation of physiological or abnormal conditions is closely connected with slight changes in $\mathrm{H}_{2} \mathrm{O}_{2}$ levels. However, the generation and degradation of $\mathrm{H}_{2} \mathrm{O}_{2}$ are variable within different cellular compartment, and this small molecule is highly diffusive, rendering difficult the detection of small $\mathrm{H}_{2} \mathrm{O}_{2}$ fluctuations and the study of its spatial and temporal dynamics. Therefore, the development of selective and sensitive tools allowing $\mathrm{H}_{2} \mathrm{O}_{2}$ detection in a biological context represents a great challenge for a better understanding of $\mathrm{H}_{2} \mathrm{O}_{2}$-mediated signalling in physiological and pathological processes.
Among numerous strategies developed to detect $\mathrm{H}_{2} \mathrm{O}_{2}$, "off-on" small fluorescent probes have attracted particular attention due to their easy implementation, high expected signal-to-noise ratio, and compatibility with standard equipment present in cellular biology research environments. ${ }^{[4]}$ The fluorescence of such probes is triggered or modified by $\mathrm{H}_{2} \mathrm{O}_{2}$-mediated transformation of a suitable chemical moiety. Several approaches have been explored including probes based on arylsulfonyl esters hydrolysis, ${ }^{[5]}$ oxidation of arylboronates, ${ }^{[6]}$ Baeyer-Villiger oxidation of diketones, ${ }^{[7]}$ Tamao oxidation of silanes ${ }^{[8]}$ or a tandem Payne-Dakin reaction. ${ }^{[9]}$ Among them, probes based on the boronate esters oxidation pioneered by Chang are the most explored sensors, due to their remarkable stability, low toxicity profile, ease of preparation and their specificity towards $\mathrm{H}_{2} \mathrm{O}_{2} \cdot{ }^{[10]}$ Upon reaction with $\mathrm{H}_{2} \mathrm{O}_{2}$, these compounds undergo an oxidative conversion into aryl borate esters that further hydrolyse into the corresponding fluorescent phenols along with borate esters or boric acid (Scheme 1A). This conversion turns on probe fluorescence either directly or via the degradation of a self-immolative spacer. This chemospecific and biologically compatible reaction allowed for developing highly selective fluorescent probes for $\mathrm{H}_{2} \mathrm{O}_{2}$ imaging in cells. ${ }^{[1]}$ However, $\mathrm{H}_{2} \mathrm{O}_{2}-$ triggered conversion of boronic acids to fluorescent phenols is still not satisfactory since most of these probes have second order reaction rate constants of $0.1-1.0 \mathrm{~m}^{-1} . \mathrm{s}^{-1} .{ }^{[12]}$ In cells, $\mathrm{H}_{2} \mathrm{O}_{2}$ is present in the 1-100 $\mathrm{nM}$ concentration range in physiological conditions and could reach up to $100 \mu \mathrm{M}$ under oxidative stress conditions. ${ }^{[13]}$ Therefore, most of the boronate-based probes need an incubation time longer than 30 minutes to detect a $\mathrm{H}_{2} \mathrm{O}_{2}$ concentration of $100 \mu \mathrm{M}$. Thus, alternative $\mathrm{H}_{2} \mathrm{O}_{2}$ sensors with rapid reaction rates allowing real-time monitoring of $\mathrm{H}_{2} \mathrm{O}_{2}$ are still expected. 


\section{A. Current boronate-based $\mathrm{H}_{2} \mathrm{O}_{2}$ sensors

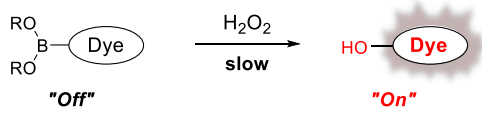 \\ $\mathrm{R}=$ pinacol or hydrogen}

B. This study: borinic-based $\mathrm{H}_{2} \mathrm{O}_{2}$ sensor

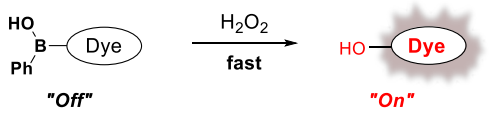

Scheme 1. Principle of "Off-On" fluorescent probes for $\mathrm{H}_{2} \mathrm{O}_{2}$ detection. A Current boronate-based $\mathrm{H}_{2} \mathrm{O}_{2}$ sensors. B. This study: a new borinic-based $\mathrm{H}_{2} \mathrm{O}_{2}$ sensor.

To address this issue, we envisioned the use of borinic acids, which due to electronic effects could be more prone to rapid oxidation compared to their boronic acid counterpart. These structures have been mainly exploited as catalysts for their electrophilic properties in various reactions such as epoxide ring opening, ${ }^{[14]}$ hydrosilylation, ${ }^{[15]}$ transamidation, ${ }^{[16]}$ aldol reaction, ${ }^{[17]}$ selective monoalkylation of diol ${ }^{[18]}$ or regioselective glycosylation reactions. ${ }^{[19]}$ Surprisingly, the reactivity of these borinic species, remains underexplored, probably due to their limited synthetic routes. ${ }^{[20]}$ They were usually obtained through the addition of strong organometallic reagents $(\mathrm{RLi} / \mathrm{RMgBr})$ onto boron-based electrophiles such as trialkylborates, boron halides, diborane or boronate esters. To date, a detailed study of the reactivity of borinic acids towards oxidation including reaction with hydrogen peroxide has not been reported and their use as a trigger for the direct release of a probe has never been considered.

Herein, we report for the first time the design and the synthesis of a new borinic sensor for the direct detection of the hydrogen peroxide molecule (Scheme 1B). We establish a detailed kinetic analysis of the $\mathrm{H}_{2} \mathrm{O}_{2}$-promoted oxidation of this new fluorogenic borinic acid as well as a comparative study with its corresponding boronic analogue, which has never been carried out yet. Furthermore, we demonstrate the efficiency of the borinic trigger toward $\mathrm{H}_{2} \mathrm{O}_{2}$-mediated oxidation in a cellular context.

First, in order to validate the general approach, we compared the reactivity of simple model compounds towards $\mathrm{H}_{2} \mathrm{O}_{2}$, i.e., phenylborinic acid synthesized from addition of phenyl lithium onto pinacol phenylboronate ${ }^{[20 b][21]}$ and the commercially available phenylboronic acid. These two compounds were submitted to oxidation with one equivalent of $\mathrm{H}_{2} \mathrm{O}_{2}$ in deuterated PBS buffer ( $\mathrm{pH}$ 7.4). The reaction progress was monitored using ${ }^{1} \mathrm{H}$ NMR spectroscopy. These early experiments were extremely encouraging since we observed a complete oxidation of the phenylborinic acid into phenol and phenylboronic acid within 2 minutes whereas 2 hours were required for full conversion of the phenylboronic acid into phenol under the same conditions (Scheme S1).

Capitalizing on these preliminary results, we focused on the synthesis of a borinic acid-based fluorogenic probe containing a phenyl moiety and a simple coumarin scaffold in order to validate our proof of concept. The synthetic route involved a four-step sequence in which the key reaction relies on the addition of phenyl lithium onto a coumarin-based pinacol boronic ester (Scheme 2A). Thus, treatment of 4-methylumbelliferone (4MU) with trifluoromethanesulfonic anhydride afforded the corresponding triflate 1 in $97 \%$ yield, which was subjected to a Pd-catalyzed cross coupling reaction with bis(pinacolato)diboron under microwave irradiation according to Chang's conditions. ${ }^{[11 \mathrm{~b}][22]}$ The resulting pinacol boronic ester 2 was then reacted with a solution of phenyl lithium to afford the borinic acid, ${ }^{[23]}$ which was immediately converted into the corresponding $\mathrm{N}, \mathrm{N}$-dimethylaminoethyl ester $3 .{ }^{[24]}$ This compound was isolated by precipitation in $24 \%$ yield over two steps. ${ }^{[25]}$ Acidic hydrolysis provided the expected borinic acid 4 in $67 \%$ yield. The corresponding 4-methyl coumarin boronic acid $\mathbf{5}$ was also synthesized for comparison. It was easily obtained from the pinacol ester using recently reported transesterification reaction with methylboronic acid (Scheme 2B). ${ }^{[26]}$

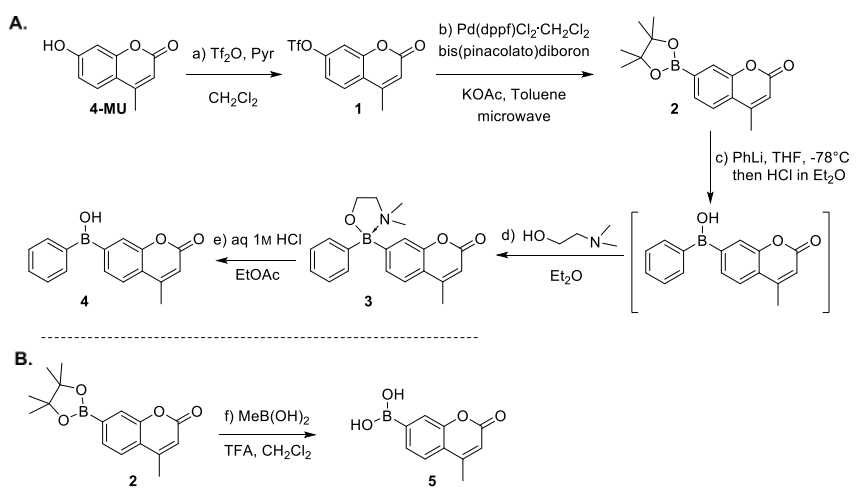

Scheme 2. Synthesis of 4-methylcoumarin-based borinic acid (A) Conditions: a) $\mathrm{Tf}_{2} \mathrm{O}$ (1.1 equiv), Pyr (2.2 equiv), $\mathrm{CH}_{2} \mathrm{Cl}_{2}, \mathrm{RT}, 2 \mathrm{~h}, 97 \%$; b) bis(pinacolato)diboron (1.2 equiv), KOAc (1.5 equiv), $\mathrm{Pd}(\mathrm{dppf}) \mathrm{Cl}_{2} \cdot \mathrm{CH}_{2} \mathrm{Cl}_{2}$ (10 mol\%), toluene, microwave irradiation, $120^{\circ} \mathrm{C}, 3 \mathrm{~h}, 65 \%$; c) $\mathrm{PhLi}$ in $n-\mathrm{Bu}_{2} \mathrm{O}(c$ $1.9 \mathrm{M}, 1.1$ equiv), $-78^{\circ} \mathrm{C}, 4 \mathrm{~h}$ then $\mathrm{HCl}$ in $\mathrm{Et}_{2} \mathrm{O}$ (c $2 \mathrm{M}, 7$ equiv), $-78^{\circ} \mathrm{C}$ to $\mathrm{RT}$; d) $\mathrm{N}, \mathrm{N}$-dimethylethanolamine (2 equiv), $\mathrm{Et}_{2} \mathrm{O}, \mathrm{RT}, 12 \mathrm{~h}, 24 \%$; e) $\mathrm{HCl}$, EtOAc, $\mathrm{RT}$, $30 \mathrm{~min}, 67 \%$; Synthesis of 4-methylcoumarin boronic acid (B): $f$ ) $\mathrm{MeB}(\mathrm{OH})_{2}$, TFA, $\mathrm{CH}_{2} \mathrm{Cl}_{2}, \mathrm{RT}, 4 \mathrm{~h}, 87 \%$.

Hydrogen peroxide-mediated oxidation of $\mathbf{4}$ and $\mathbf{5}$ was first monitored by ${ }^{1} \mathrm{H}$ NMR spectroscopy in deuterated PBS buffer $(\mathrm{pH} 7.4)$. As previously observed with the phenyl-based model compounds, the borinic derivative was found to be more reactive than its boronic counterpart. Thus, the addition of $\mathrm{H}_{2} \mathrm{O}_{2}$ triggers full oxidation of the borinic acid 4 in less than 2 minutes. In contrast, the boronic acid 5 is gradually converted into $4-\mathbf{M U}$ to reach complete conversion within 2.5 hours (Scheme S2). Due to the dissymmetrical nature of the borinic acid probe, the oxidative rearrangement of 4 leads to the formation of two different alcohol/boronic acid couples, i.e. either phenol/4methylcoumarin boronic acid $\mathbf{5}$ as the undesired cleavage products, or 4-MU/phenylboronic acid as the expected cleavage products. The ratio of both was determined by ${ }^{1} \mathrm{H}$ NMR integration and was evaluated to be $80 / 20$ against the direct release of 4-MU (Figure 1). 


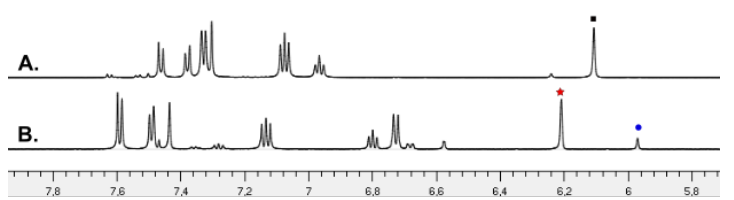

c.

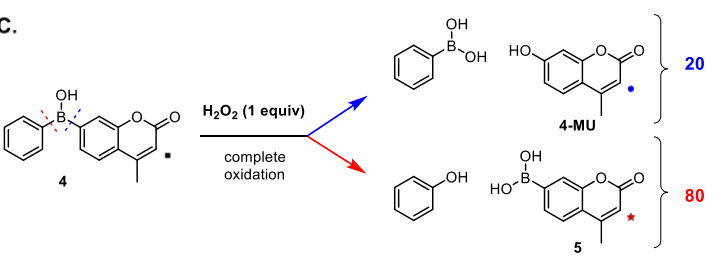

Figure 1. Regioselectivity of the oxidation of probe 4 determined by ${ }^{1} \mathrm{H}$ NMR spectroscopy $(600 \mathrm{MHz})$ in deuterated PBS buffer ( $\mathrm{pH} 7.4,0.2 \%$ DMSO). ${ }^{1} \mathrm{H}$ NMR spectra of the borinic acid $\mathbf{4}(\mathbf{A})$ and $\mathbf{4}$ with $\mathrm{H}_{2} \mathrm{O}_{2}$-urea complex (1 equiv) after 2 minutes (B). (C) The two different couples of alcohol/boronic acid resulting from the oxidation reaction. 4-MU=4-methylumbelliferone.

Having demonstrated the higher reactivity of the borinicbased probe, we then undertook the accurate determination of the kinetic constants of the oxidation reactions (Figure 2A). To calculate these parameters, we used real-time measurement of the fluorescence emission performed under pseudo-first order conditions (excess of oxidant). Initial $\mathrm{H}_{2} \mathrm{O}_{2}$-promoted oxidation experiments were conducted with boronic acid $\mathbf{5}$ at different temperatures and $\mathrm{H}_{2} \mathrm{O}_{2}$ concentrations. As expected, reaction with $\mathrm{H}_{2} \mathrm{O}_{2}$ leads to an increase in fluorescence emission at 450 $\mathrm{nm}$ indicating the release of the 4-MU chromophore (Figure $2 \mathrm{C}$ ).

A.
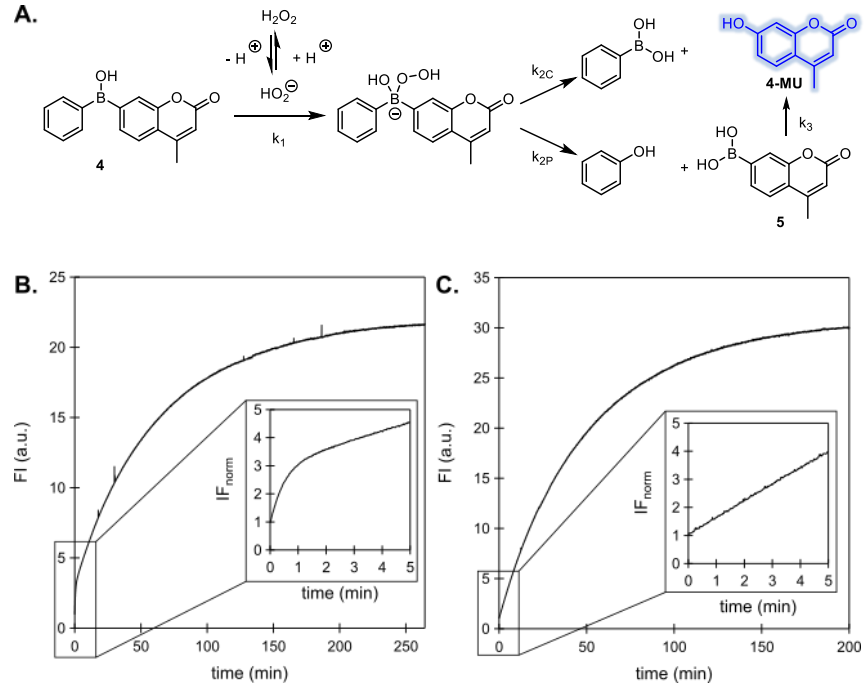

Figure 2. Kinetic study of oxidation of probe 4 and boronic acid 5. (A) Simplified kinetic scheme of oxidation of the borinic acid 4. (B,C) Timedependent fluorescence intensity evolution of $5 \mu \mathrm{M} 5$ (C) or 4 (B). Upon addition of $100 \mu \mathrm{M} \mathrm{H}_{2} \mathrm{O}_{2}$-urea solution in PBS buffer $1 \mathrm{X}(\mathrm{pH} \mathrm{7.4,0.04 \%}$ $\mathrm{DMSO}$ ) at $310 \mathrm{~K}$ (pseudo-first order conditions). The fluorescence emission was normalized and was recorded at $\lambda_{\mathrm{em}}=450 \mathrm{~nm}\left(\lambda_{\mathrm{ex}}=405 \mathrm{~nm}\right)$.

For kinetic analysis of the experimental data, a model including the different steps involved in the 4-MU release was taken into account allowing to determine the second order rate constant $\mathrm{k}_{3}$ associated with the oxidation as $1.8 \mathrm{M}^{-1} . \mathrm{s}^{-1}$ and $6.3 \mathrm{M}^{-}$ ${ }^{1} . \mathrm{S}^{-1}$ at 293 and $310 \mathrm{~K}$, respectively (Figure S4). These results are consistent with those previously reported in the literature. ${ }^{[27]}$
In comparison, oxidation of borinic derivative $\mathbf{4}$ shows a different behaviour. Upon addition of $\mathrm{H}_{2} \mathrm{O}_{2}$, fluorescence rapidly increases, which suggests an oxidation of the borinic acid probe 4 at the minute timescale affording directly 4-MU through the desired but minor oxidation pathway. After a few minutes, fluorescence increases more slowly, at a time scale which is in line with the formation of 4-MU from the boronic acid $\mathbf{5}$ obtained as a major product from oxidizing probe 4 (Figure 2B). Upon considering that several reactions are rapid at the timescale of the overall oxidation process $(E S I+)$, we could account for the oxidation of the borinic acid 4 with the reduced mechanism shown in Figure 2A. After integration of the kinetic results obtained above for the boronic acid 5 , we extracted $1.9 \times 10^{4}$ and $4.2 \times 10^{4} \mathrm{M}^{-1} \cdot \mathrm{s}^{-1}$ for the rate constant $\mathrm{k}_{1}$ at 293 and $310 \mathrm{~K}$, respectively (see ESI $\uparrow$ for the determination). These results point to an oxidation of the borinic trigger which is about 10000 times faster than for its boronic counterpart.

Based on these promising results, we furthermore investigated the ability of the borinic-based probe to detect hydrogen peroxide in a cellular environment. For this purpose, we used $\operatorname{COS} 7$ cells stably expressing the two membrane subunits of the NADPH oxidase (COS79p91-p22 cells). Upon transfection with a chimeric protein named trimera and composed of the domains necessary for the activation of the oxidase, the cells continuously produce superoxide radical anion (see SI for details on the trimera). ${ }^{[28]}$ Since superoxide spontaneously dismutates into $\mathrm{H}_{2} \mathrm{O}_{2}$ in aqueous buffer, ${ }^{[29]}$ these cells constitute an interesting model to investigate the sensitivity of the probe for endogenous ROS detection. A preliminary experiment was performed with non-transfected COS7gp91-p22 cells in the presence of $10 \mu \mathrm{M}$ borinic acid 4 . Upon addition of an exogenous solution of hydrogen peroxide (final concentration $100 \mu \mathrm{M})$, fluorescence intensity at $450 \mathrm{~nm}$ increases rapidly within a few minutes and then more slowly, as observed during the in vitro kinetic study (Figure S8). Control experiment performed without $\mathrm{H}_{2} \mathrm{O}_{2}$ resulted in an absence of fluorescence signal providing evidence for the reactivity of the borinic acid toward exogenous hydrogen peroxide in a cellular context. We then focused on the ability of probe 4 to detect endogenous $\mathrm{H}_{2} \mathrm{O}_{2}$ generated by NADPH oxidase. Thus, fluorescence signal was monitored upon addition of the borinic probe $\mathbf{4}$ and its boronic counterpart $\mathbf{5}$ on either transfected cells, which continuously produce hydrogen peroxide, or non-transfected cells as control experiments (Figure 3).

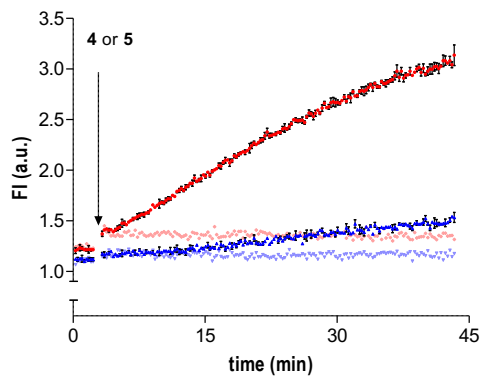

Figure 3. Fluorophore release in a cellular context. Time-dependent fluorescence intensity of $10 \mu \mathrm{M}$ borinic probe $\mathbf{4}$ (red curve) or $10 \mu \mathrm{M}$ boronic acid 5 (blue curve) in transfected $\operatorname{COS} 7^{\mathrm{gp} 91 / \mathrm{p} 22}$ cells. Negative controls in nontransfected COS7gp91/p22 cells for the borinic probe 4 (light red curve) and the boronic acid 5 (light blue curve). Data were recorded in PBS buffer $1 \mathrm{X}(\mathrm{pH} 7.4$, $0.02 \% \mathrm{DMSO})$ at $310 \mathrm{~K}$, at $\lambda_{\mathrm{em}}=450 \mathrm{~nm}\left(\lambda_{\mathrm{ex}}=360 \mathrm{~nm}\right)$. 
In the case of cells expressing an activated oxidase, the borinic acid probe 4 generated a significantly more intense fluorescence signal than the boronic probe $\mathbf{5}$ under the same conditions. The ratio of the two slopes indicates that $\mathbf{4 - M U}$ is released 10 -fold faster with the borinic probe than with the boronic one, which is in a reasonable agreement with the theoretical value determined by our kinetic studies (see ESI $\dagger$ ). Moreover, no fluorescence increase was observed either using non-transfected COS- $7^{\text {gp91/p22 }}$ cells (Figure 3, light curves), or in the presence of diphenyleneiodonium chloride (DPI), a NADPH oxidase inhibitor, or catalase, an enzyme which catalyses $\mathrm{H}_{2} \mathrm{O}_{2}$ dismutation (Figure S9). All these control experiments provide evidences for the reactivity of the probe 4 toward endogenous hydrogen peroxide. These results clearly support the borinic trigger as a suitable tool for endogenous $\mathrm{H}_{2} \mathrm{O}_{2}$ detection in a physiological environment.

In conclusion, we have described the first example of a borinic-based probe enabling direct fluorophore release upon $\mathrm{H}_{2} \mathrm{O}_{2}$-mediated oxidation. Through detailed kinetic studies, we demonstrated that this coumarin-containing borinic sensor responded to $\mathrm{H}_{2} \mathrm{O}_{2}$ in an unprecedented short time, even when $\mathrm{H}_{2} \mathrm{O}_{2}$ is endogenously produced by cells. Optimizations are now underway in the laboratory to control the regioselectivity of probe oxidation and get improved sensors in terms of spectral properties and brightness for imaging. Noteworthy this work has revealed the superior reactivity of the borinic trigger toward $\mathrm{H}_{2} \mathrm{O}_{2}$-promoted oxidation compared to the corresponding boronic counterpart, rendering the borinic trigger a valuable tool for hydrogen peroxide detection. Such favorable features should also secure promising applications of this new trigger for drug release and theranostics.

\section{Acknowledgements}

The authors would like to thank Prof. Arnaud Gautier for preliminary cellular studies. We thank the Ministère de l'Enseignement Supérieur, de la Recherche et de l'Innovation for a PhD grant to R.O. and IDEX Paris Saclay for a PhD grant to B.G.-F. This work was supported by IDEX Paris Saclay (IRS BioProbe). We also thank the French Agency for Research for funding preliminary studies (grant ANR-12-BS07-0022 ROSAS).

Keywords: borinic acid • fluorescent probes $\cdot \mathrm{H}_{2} \mathrm{O}_{2}$ detection • oxidative stress $\bullet$ kinetics

[1] a) E. A. Veal, A. M. Day, B. A. Morgan, Mol. Cell 2007, 26, 1-14; b) N. Di Marzo, E. Chisci, R. Giovannoni, Cells 2018, 7, 156-172.

[2] T. Finkel, M. Serrano, M. A. Blasco, Nature 2007, 448, 767-774.

[3] a) J. K. Andersen, Nat. Rev. Neurosci. 2001, 10, S18-S25; b) L. Park, P. Zhou, R. Pitstick, C. Capone, J. Anrather, E. H. Norris, L. Younkin S. Younkin, G. Carlson, B. S. McEwen, C. Iadecola, Proc. Natl. Acad. Sci. U.S.A. 2008, 105, 1347-1352.

[4] a) D.-J. Zheng, Y.-S. Yang, H.-L. Zhu, TrAC Trends Anal. Chem. 2019, 118, 625-651; b) H. Guo, H. Aleyasin, B. C. Dickinson, R. E. HaskewLayton, R. R. Ratan, Cell Biosci. 2014, 4, 64; c) X. Chen, X. Tian, I. Shin, J. Yoon, Chem. Soc. Rev. 2011, 40, 4783-4804.
[5] H. Maeda, Y. Fukuyasu, S. Yoshida, M. Fukuda, K. Saeki, H. Matsuno, Y. Yamauchi, K. Yoshida, K. Hirata, K. Miyamoto, Angew. Chem. Int. Ed. 2004, 43, 2389-2391; Angew. Chem. 2004, 116, 2443-2445.

[6] L.-C. Lo, C.-Y. Chu, Chem. Commun. 2003, 2728-2729.

[7] M. Abo, Y. Urano, K. Hanaoka, T. Terai, T. Komatsu, T. Nagano, J. Am. Chem. Soc. 2011, 133, 10629-10637.

[8] X. Zhou, L. Lesiak, R. Lai, J. R. Beck, J. Zhao, C. G. Elowsky, H. Li, C. I. Stains, Angew. Chem. Int. Ed. 2017, 56, 4197-4200; Angew.Chem. 2017, 129, 4261-4264.

[9] S. Ye, J. J. Hu, D. Yang, Angew. Chem. Int. Ed. 2018, 57, 1017310177; Angew. Chem. 2018, 130, 10330-10334.

[10] For reviews, see: a) A. R. Lippert, G. C. Van de Bittner, C. J. Chang, ACC. Chem. Res. 2011, 44, 793-804; b) X. Chen, F. Wang, J. Y. Hyun, T. Wei, J. Qiang, X. Ren, I. Shin, J. Yoon, Chem. Soc. Rev. 2016, 45, 2976-3016; c) Y. Liu, C. Jiao, W. Lu, P. Zhang, Y. Wang, RSC Adv. 2019, 9, 18027-18041.

[11] For selected articles, see: a) M. C. Y. Chang, A. Pralle, E. Y. Isacoff, C J. Chang, J. Am. Chem. Soc. 2004, 126, 15392-15393; b) B. C. Dickinson, C. Huynh, C. J. Chang, J. Am. Chem. Soc. 2010, 132, 59065915; c) V. S. Lin, B. C. Dickinson, C. J. Chang, Methods Enzymol. 2013, 526, 19-43; d) W. Wu, J. Li, L. Chen, Z. Ma, W. Zhang, Z. Liu, Y. Cheng, L. Du, M. Li, Anal. Chem. 2014, 86, 9800-9806; e) P. Wang, K. Wang, D. Chen, Y. Mao, Y. Gu, RSC Adv. 2015, 5, 85957-85963.

[12] B. Kalyanaraman, M. Hardy, J. Zielonka, Curr. Pharmcol. Rep. 2016, 193-201.

[13] H. Sies, Redox Biol. 2017, 11, 613-619.

[14] G. Wang, G. E. Garrett, M. S. Taylor, Org. Lett. 2018, 20, 5375-5379.

[15] A. Chardon, J. Rouden, J. Blanchet, Eur. J. Org. Chem. 2019, 995-998.

[16] T. Mohy El Dine, D. Evans, J. Rouden, J. Blanchet, Chemistry 2016, 22, 5894-5898.

[17] D. Lee, S. G. Newman, M. S. Taylor, Org. Lett. 2009, 11, 5486-5489.

[18] a) L. Chan, M. S. Taylor, Org. Lett. 2011, 13, 3090-3093; b) D. Lee, C. L. Williamson, L. Chan, M. S. Taylor, J. Am. Chem. Soc. 2012, 134, 8260-8267.

[19] a) T. M. Beale, M. S. Taylor, Org. Lett. 2013, 15, 1358-1361; b) M. Tanaka, D. Takahashi, K. Toshima, Org. Lett. 2016, 18, 5030-5033.

[20] a) H. C. Brown, M. Srebnik, T. E. Cole, Organometallics 1986, 5, 23002303 ; b) A. Hofer, G. Kovacs, A. Zappatini, M. Leuenberger, M. A. Hediger, M. Lochner, Bioorg. Med. Chem. 2013, 21, 3202-3213; c) L. Marciasini, B. Cacciuttolo, M. Vaultier, M. Pucheault, Org. Lett. 2015, 17, 3532-3535; d) C. Guan, L. Huang, C. Ren, G. Zou, Org. Process Res. Dev. 2018, 22, 824-828.

[21] T. Mohy El Dine, J. Rouden, J. Blanchet, Chem. Commun. 2015, 51, 16084-16087.

[22] T. Ishiyama, T, Y. Itoh, T. Kitano, N. Miyaura, Tetrahedron Lett. 1997, 38, 3447-3450.

[23] Changing 4-methylumbelliferone to umbelliferone affords the expected borinic acid in only $4 \%$ yield.

[24] We found that the hydrolysis of 2-aminoethyl ester is more efficient than the 8-hydroxyquinolein counterpart.

[25] The reaction with 8-hydroxyquinoline gave the same yield.

[26] S. P. A. Hinkes, C. D. P. Klein, Org. Lett. 2019, 21, 3048-3052.

[27] a) A. Sikora, J. Zielonka, M. Lopez, J. Joseph, B. Kalyanaraman, Free Radic. Biol. Med. 2009, 47, 1401-1407; b) J. N. LaButti, K. S. Gates, Bioorg. Med. Chem. Lett. 2009, 19, 218-221; c) W. Wu, J. Li, L. Chen, Z. Ma, W. Zhang, Z. Liu, Y. Cheng, L. Du, M. Li, Anal. Chem. 2014, 86, 9800-9806; d) N. Rios, L. Piacenza, M. Trujillo, A. Martínez, V. Demicheli, C. Prolo, M. Noel Álvarez, G. V. López, R. Radi, Free Radic. Biol. Med. 2016, 101, 284-295.

[28] R. Masoud, X. Serfaty, M. Erard, P. Machillot, G. Karimi, E. Hudik, F. Wien, L. Baciou, C. Houée-Levin, T. Bizouarn, Free Radic. Biol. Med. 2017, 113, 470-477.

[29] C. C. Winterbourn, M. B. Hampton, J. H. Livesey, A. J. Kettle, J. Biol. Chem. 2006, 281, 39860-39869. 